\title{
Frequency of Aedes sp. Linnaeus (Diptera: Culicidae) and Associated Entomofauna in Bromeliads from a Forest Patch within a densely Urbanized Area
}

\author{
TN Docile ${ }^{1,2,3,4,5}$, R Figueiró ${ }^{5,6,7}$, NA Honório ${ }^{8,2}$, DF Baptista ${ }^{9}$, G Pereira ${ }^{2}$, JAA dos Santos ${ }^{9}$, \\ CT CODEÇO ${ }^{2,3}$
}

\author{
${ }^{1}$ Lab de Entomologia, Depto de Zoologia, Inst. de Biologia, Univ Federal do Rio de Janeiro (UFRJ), CCS, Rio de Janeiro, Brasil \\ ${ }^{2}$ Núcleo Operacional Sentinela de Mosquitos Vetores (Nosmove)- Fundação Oswaldo Cruz, Rio de Janeiro, Brasil \\ ${ }^{3}$ Programa de Computação Científica-Fundação Oswaldo Cruz, Rio de Janeiro, Brasil \\ ${ }^{4}$ Programa de Pós-Graduação em Ecologia da Univ Federal do Rio de Janeiro (UFRJ), Rio de Janeiro, Brasil \\ ${ }^{5}$ Lab de Biotecnologia Ambiental, Centro Universitário Estadual da Zona Oeste (UEZO), Rio de Janeiro, Brasil \\ ${ }^{6}$ Centro Universitário de Volta Redonda (UniFOA), Volta Redonda, Brasil \\ ${ }^{7}$ Programa de Pós-Graduação em Ciência e Tecnologia Ambiental do Centro Universitário Estadual da Zona Oeste (UEZO), Rio de \\ Janeiro, Brasil \\ ${ }^{8}$ Lab de Transmissores de Hematozoários-IOC/ Fundação Oswaldo Cruz, Rio de Janeiro, Brasil \\ ${ }^{9}$ Lab de Avaliação e Promoção da Saúde Ambiental -IOC/ Fundação Oswaldo Cruz, Rio de Janeiro, Brasil
}

\section{Keywords}

Mosquitoes, Macroinvertebrates, Abiotic variables, Forest fragment, Urban area

\section{Correspondence \\ TN Docile, Lab de Entomologia, Depto de Zoologia, Inst. de Biologia, Univ Federal do Rio de Janeiro (UFRJ), CCS, Bloco A, sala A1- 107, Av. Carlos Chagas Filho, 373, Rio de Janeiro, Brasil; tatidocile@gmail.com \\ Edited by Eunice Galati - INPA \\ Received 1 December 2015 and accepted 16 February 2017 \\ Published online: 18 March 2017 \\ (C) Sociedade Entomológica do Brasil 2017}

\begin{abstract}
Little is known about the relationship between the presence of Aedes, abiotic factors and the entomofauna existing in phytotelmatas. The aim of this study was to identify biotic and abiotic factors associated with the presence of Aedes in bromeliads sites located in a forest fragment in Rio de Janeiro, Brazil. In the study area, eight bromeliads from the Aechmea genus were chosen and kept in landscape form. Physical and chemical variables were measured. Collected aquatic insects were identified according to the literature. A total of 3102 immature insects were collected. The presence of Aedes aegypti (Linnaeus) (2.29\%) was rare. Few specimens were found concentrated in urban-adjacent areas during summer. On the other hand, Aedes albopictus (Skuse) (17.57\%) was found throughout the year in $0 \%-80 \%$ of the sites, averaging $1.0 \mathrm{mosq} / \mathrm{bromelia}$. Aedes albopictus was found predominantly in central sites of the forest fragment. The Canonical Correspondence Analysis indicates that most taxa had a moderate association with temperature, dissolved oxygen, and $\mathrm{pH}$. The abiotic variables, such as temperature and dissolved oxygen, affect the distribution of the genus Aedes vectors, while most of the other variables did not.
\end{abstract}

\section{Introduction}

The Bromeliaceae family is characterized by the ability to store water, offering favorable conditions to house aquatic invertebrates (Frank 1983). In these phytotelmatas, colonization and maintenance of aquatic organisms are mediated by environmental processes, such as interactions among species (Richardson et al 2000). From the anthropic perspective, bromeliads are classified as natural or artificial containers. Some exist in the wild and others are cultivated for landscaping purposes, residences, and city parks (Forattini et al 1998). Several mosquito species use bromeliads as breeding sites; for example those of Sabetini (Forattini 2002) and of other groups which have been found naturally infected with arboviruses and other medically-important parasites (Consoli \& Lourenço-deOliveira 1994, Lounibos et al 2003, Gadelha 1994). 
In addition to the fact that the bromeliads capture rainwater passively, they can also actively change the physico-chemical conditions of their microcosm, absorbing nutrients through specialized trichomes (Benzing et al 1972, Inselsbacher et al 2007). Lopez et al (2009) proposed that this special micro environmental condition created by the physiology of bromeliads acts as an environmental filter that restricts the number of potential settlers. The $\mathrm{pH}$ of the water in the bromeliad also drops sharply, probably related to ion exchange mediated by the absorption of the bromeliad metabolism (Lopez et al 2009). The variation of abiotic factors is important for colonization and the development of aquatic biota in these phytotelmatas (Forattini 2002).

Ten arboviruses have recently been reviewed as important emergent disease agents in Brazil (Figueiredo 2007), of which Aedes aegypti (Linnaeus 1762) can transmit dengue virus (DENV), yellow fever virus (YFV), Chikungunya virus (CHIKV) (Figueiredo \& Figueiredo 2014), Venezuelan equine encephalitis virus (VEEV) (Ortiz et al 2008), Mayaro virus (MAYV) (Aitken \& Anderson 1959, Figueiredo \& Figueiredo 2014) and Zika vírus (ZIKV) (loos et al 2014). The distribution and frequency of Ae. aegypti is associated with the presence of environments altered by man, being essentially characterized as a mosquito of peridomicile and human dwellings (Christophers 1960). This mosquito is considered rare in natural habitats, such as bromeliads (Consoli \& Lourenço-de-Oliveira 1994). However, it is occasionally found in these natural containers in the Americas (Peryassú 1908, Forattini \& Marques 2000, Marques et al 2001, Cunha et al 2002, O'Meara et al 2003, Varejão et al 2005, Maciel-de-Freitas et al 2007). Aedes albopictus (Skuse 1894) uses different natural breeding sites, such as the internodes of bamboo, tree holes, and a variety of species of bromeliads (Consoli \& Lourenço-de-Oliveira 1994).

The presence of Ae. albopictus in the aquatic content of bromeliads in the urban and peri-urban environment in the Atlantic Forest was recorded by Natal et al (1997) and Marques et al (2001). Many studies have reported the presence of Ae. aegypti and Ae. albopictus in such plants only occasionally (Cunha et al 2002, O'Meara et al 2003, Maciel-de Freitas et al 2007, David et al 2009). In the study by Honorio et al (2009), Ae. albopictus was present in a forest fragment in a densely-urbanized area. However, little is known about the relationship between the presence of these two vectors and the influence of biotic and abiotic factors in the phytotelmatas. In terms of public health, ecological conditions that influence the abundance of mosquito diseases are of great interest because they may help define management strategies that, combined, minimize the risk to human health and the preservation of the environment (Chaves \& Koenraadt 2010).

The aim of this study was to identify biotic and abiotic factors associated with the presence of Ae. aegypti and Ae. albopictus in bromeliad sites, located in a forest fragment imbedded in a densely-populated area endemic for dengue. In addition, this study assessed whether there is spatial and temporal variation in the presence and frequency of vectors in bromeliads.

\section{Material and Methods}

\section{Study area}

The study was conducted in a transition zone between an urban area and a forest area located on the campus of Oswaldo Cruz Foundation, Rio de Janeiro, Brazil ( $22^{\circ} 52^{\prime} 30^{\prime \prime}$ $\mathrm{S}, 43^{\circ} 14^{\prime} 53^{\prime \prime} \mathrm{W} ; 697.000 \mathrm{~m}^{2}$ ). This region has a heterogeneous vegetation cover characterized by low, medium, and high vegetation, consisting of species of the Atlantic Forest biome and introduced species of landscape form, under constant management actions. The surrounding area consists of slums (Lenzi et al 2000, Costa \& Fernandes 2009). The climate in Rio de Janeiro is tropical, with a dry winter (May to September) and rainy summer (November to March). In the study area, eight sites of bromeliads of the genus Aechmea belonging to a landscape were chosen and surveyed. These sites were referenced as $\mathrm{A}$ through $\mathrm{H}$ and were located in areas with different degrees of vegetation and urbanization (Fig 1 and Table 1).

\section{Sampling}

Immature Culicidae were collected fortnightly from August 2011 to February 2012, comprising a total of 14 samples collected during the winter of 2011, spring 2011 and summer 2012. At each site, a sample of ten bromeliads was randomly selected, and properly identified according to genus level by a specialist in these plants. During data collection, the total volume of liquid contained in each bromeliad was removed with sucking and/or pipet and filtered with the aid of a tulle. The retained immature forms (larvae and pupae) were stored in falcon tubes identified according to date and place and transported to the Sentinel Operational Unit Mosquito Vectors-NosMove (DIRAC Partnership, IOC, VPAAPS). At the time of collection, which was consistently between 8 and $11 \mathrm{am}$, water temperature and dissolved oxygen (DO) (mg O2/I) were measured using a portable oximeter (YSI F-1550 model). Of the total volume removed, 126 water samples $(500 \mathrm{ml})$ were stored, transported and refrigerated for later analysis at the Laboratory of Evaluation and Promotion of Environmental Health, Oswaldo Cruz Foundation. $\mathrm{pH}$ and alkalinity were evaluated (Gran method Camourze-Mod 1994); electrical conductivity and salinity were assessed using the electrometric method with multi-parameter; calcium, magnesium, chloride, and nitrite were measured using methods described by FUNASA 2006; and ammonia concentration was measured using the method described by Bower \& Holm-Hansen (1980). 
Fig 1 Distribution of the eight bromeliads sites (A, B, C, D, E, F, $G, H)$ located on the campus of Fiocruz, Manguinhos, Rio de Janeiro.
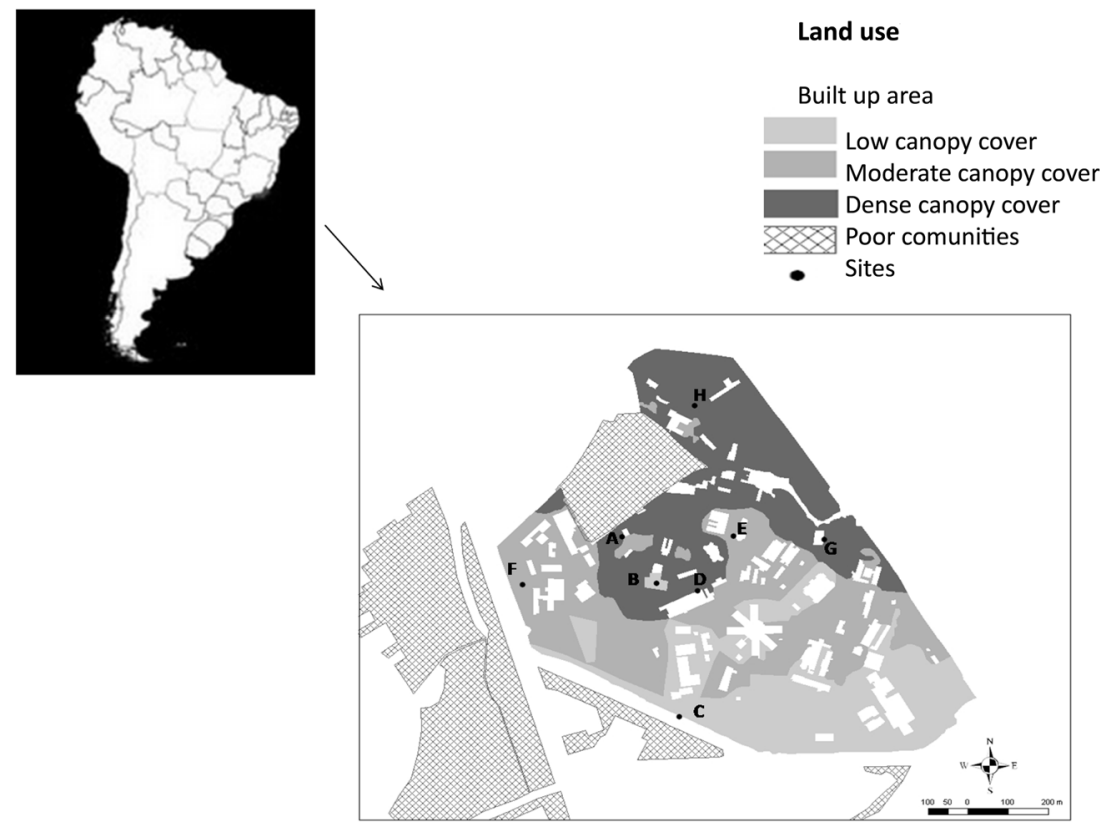

\section{Identification of immature forms}

All the collected aquatic insects were identified to the family level. Those of the family Culicidae were identified to the genus level and those of the genus Aedes to species level. The identification was carried out using a stereomicroscope, using dichotomous key (Lane 1953a, b, Forattini 1965a, b, Consoli \& Lourenço-de-Oliveira 1994, Forattini 2002, Motta et al 2007).

\section{Data analysis}

In order to describe the bromeliads' parameters, descriptive statistics of abiotic and biotic data, as the mean and standard deviation, were presented as graphs using the $R 2.8 .1$ software ( $R$ Core Team 2014). Hypothesis tests were performed (ANOVA) to determine whether there was a variation of abiotic factors of water (sample volume, temperature, dissolved oxygen, $\mathrm{pH}$, alkalinity, conductivity, salinity, concentrations of calcium, magnesium, chloride, nitrite, and ammonia) over time, between sites, and the interaction between the two. Chi-square tests were used to determine whether there were differences in the distribution of the abiotic rates found among sites. A null model test was used to identify cooccurring species using Ecosim 7.0 software (Gotelli \& Entsminger 2009) to test the hypothesis that the observed patterns of species distribution were due to chance. We used the C-score index (Stone \& Roberts 1990), which measures the units "checkerboard" between all possible pairs of species. In a community structured by competition, the C-score should be significantly smaller than expected for the null hypothesis. The following parameters were used in the null model: fixed line sums represent the abundance of individuals, the option whereby the total observed in the rows are kept in the simulation, so that the number of occurrences of each species in the null communities is the same as in the
Table 1 Characterization of eight bromeliads sites included in the study.

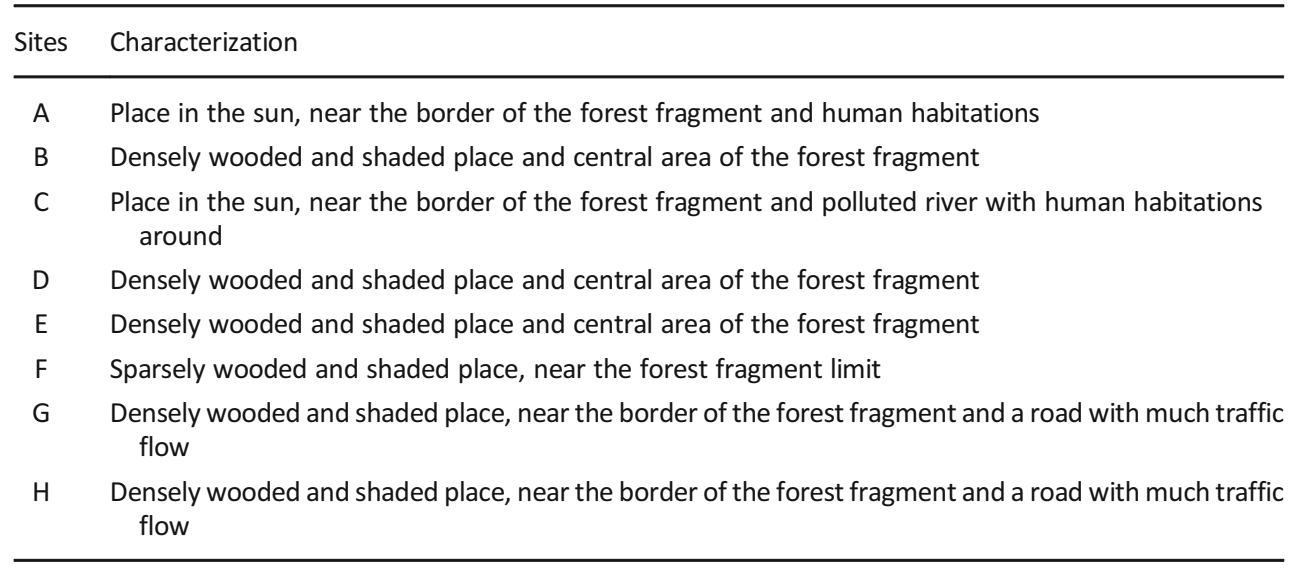


original data; and sums of equiprobable columns, configuration in which each column (or site), has equal probability of being represented. Canonical Correspondence Analysis (CCA) using CANOCO software (Ter Braak \& Smilauer 2002), relating abiotic factors, was used to measure the rate distribution. To test the significance of each environmental variable, Monte Carlo experiments with 5000 permutations were performed in the significant models $(p<0.05)$. Principal Coordinates Analysis (PCO) was used to identify possible distribution gradients of the aquatic community at different sites using the PAST program (Hammer et al 2001).

\section{Results}

\section{Abiotic variables}

The eight evaluated sites varied in their abiotic characteristics throughout the months. In summer, the average water temperature $\left(28.54^{\circ} \mathrm{C}\right)$ and dissolved oxygen $(0.49 \mathrm{~mL} / \mathrm{L})$ were higher; in winter, values of $23.16^{\circ} \mathrm{C}$ and $0.42 \mathrm{~mL} / \mathrm{L}$, respectively, were observed. In winter, the average electrical conductivity $(203 \mathrm{~S} / \mathrm{cm})$ and ammonia $(1.75 \mathrm{mmol} / \mathrm{L})$ were higher than in the hottest period $(64.3 \mathrm{~S} / \mathrm{cm}$ and $0.78 \mathrm{mmol} / \mathrm{L})$, and the other variables (sample volume, $\mathrm{pH}$, electrical conductivity, calcium concentrations, magnesium, chloride, nitrite) showed no clear seasonal patterns (Table 2). However, a significant spatial variation of values for all variables was observed except temperature, conductivity, and magnesium concentrations.

\section{Biotic variables}

We collected a total of 3102 immature insects belonging to two orders: 57 (1.84\%) of Odonata and 3045 (98.16\%) of Diptera (Table 3). All specimens of the Odonata belonging to the Megapodagrionidae family and those of Diptera, on the other hand belonging to several families: Chironomidae (44\%), Culicidae (41.14\%), Psychodidae (12.24\%) and Syrphidae (0.78\%). There were 1309 immature individuals of three genera in Culicidae: Wyeomyia (79.68\%), Aedes (19.86\%) and Toxorhynchites (0.46\%). Regarding location, Syrphidae, Toxorhynchites, Odonata, Psychodidae, Chironomidae and Wyeomyia were more abundant in central sites with high vegetation.

Two species of the genus Aedes were found. Aedes aegypti (2.29\%) was rare and few specimens were found in the summer at the sites $A, B$, and $F$. The percentage of positive sites for Ae. aegypti varied from o to $40 \%$, with an average of $0.5 \%$ (Fig 2).

Aedes albopictus (17.57\%) was collected throughout the months in $0-80 \%$ of the sites, with an average of $1.0 \%$, being
政

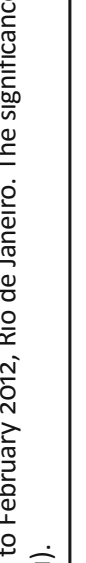

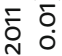

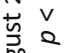

等草

인?

窎帝

苦

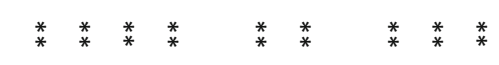

$+$

* $\quad$ * $\quad$ *

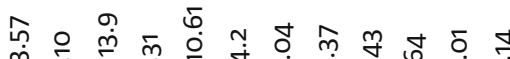

mं

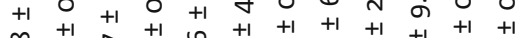

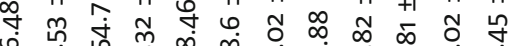

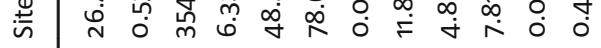

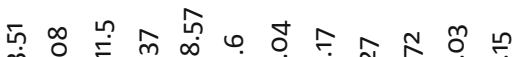

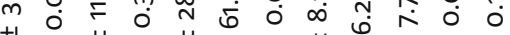

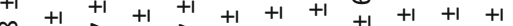

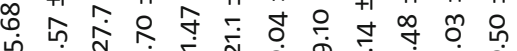

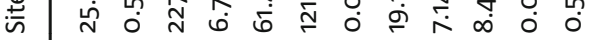
ภㅇ

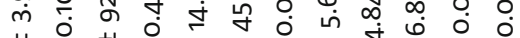

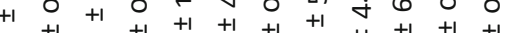

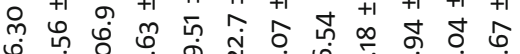
苛 कิ $\infty$ o

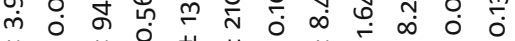

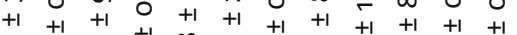
崩 站 (

œ mं 0 i

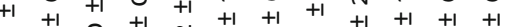

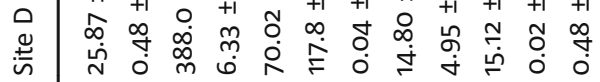

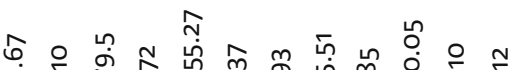

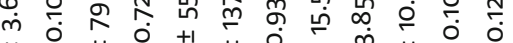

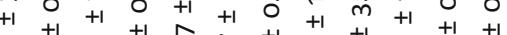

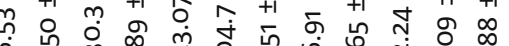
in হ.

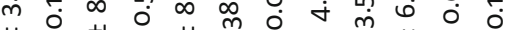

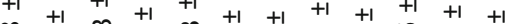

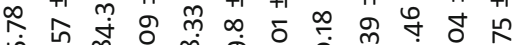
劳 峲

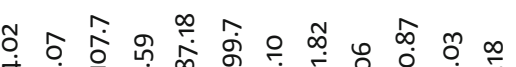

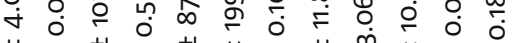

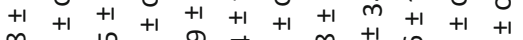

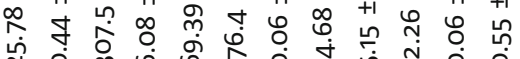

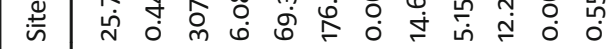


Table 3 Immature collection at sites in forest fragment (August 2011 to February 2012). The significance values are for the chisquare test of difference in the distribution of bromeliads rate between sites.

\begin{tabular}{lccccccccccc}
\hline Sites & & & & & & & & & & \\
\hline Groups & A & B & C & D & E & F & G & H & $\begin{array}{c}\text { Total } \\
\text { areas }\end{array}$ & $\begin{array}{l}\text { Test } \\
\text { (chi-sq) }\end{array}$ \\
\hline Aedes albopictus & 17 & 11 & 16 & 24 & 31 & 92 & 38 & 1 & 230 & $p<0.001$ \\
Aedes aegypti & 8 & 10 & 2 & 0 & 0 & 10 & 0 & 0 & 30 & $p<0.001$ \\
Wyeomyia sp. & 46 & 22 & 27 & 49 & 670 & 50 & 137 & 42 & 1043 & $p<0.001$ \\
Toxorhynchites sp. & 1 & 0 & 0 & 0 & 2 & 0 & 1 & 2 & 6 & $p=0.2244$ \\
Psychodidae & 23 & 23 & 45 & 80 & 12 & 158 & 21 & 11 & 373 & $p<0.001$ \\
Chironomidae & 105 & 94 & 118 & 330 & 386 & 49 & 143 & 114 & 1339 & $p<0.001$ \\
Syrphidae & 18 & 5 & 3 & 7 & 2 & 2 & 0 & 20 & 24 & $p<0.001$ \\
Megapodagrionidae & 10 & 11 & 0 & 0 & 0 & 0 & 0 & 3 & 57 & $p<0.001$ \\
Mosquitoes total & 72 & 43 & 45 & 73 & 703 & 152 & 176 & 45 & 1309 & \\
Total (associated & 156 & 133 & 166 & 417 & 400 & 209 & 164 & 148 & 1793 & \\
$\quad$ fauna) & & & & & & & & & & \\
\hline
\end{tabular}

predominantly found at sites E, F, and G, which contributed with $70 \%$ of the total specimens of this species. .

The distribution of all insects studied in bromeliads, according to the null model, was not random. It follows a structured distribution [observed index $=0.46$, with a mean of simulated indexes $=1.25$, variance in the rates of simulated $=0.09, p$ (observed $\leq$ expected) $=0.01, p$ (observed $\geq$ expected) $=0.98$ (Fig 3)

\section{Association with abiotic variables}

CCA indicates that most taxa (Ae. albopictus, Syrphidae, Megapodagrionidae, Toxorhynchites sp., Psychodidae, and Chironomidae) are positively associated with temperature, dissolved oxygen, and $\mathrm{pH}$ (Fig 4); mainly Ae. albopictus on the temperature variable. However, this species was negatively associated with the other variables, such as nitrite, ammonia, and electrical conductivity. The Wyeomyia genus was positively associated with these variables (nitrite, ammonia, conductivity). Aedes aegypti was unrelated to any of the abiotic variables measures. The variation explained by axis 1 was 0.31 and the Axis 2 is 0.28 .

PCO (Fig 5) revealed a gradient of diversity of organisms in different sites locations. Through the distribution of organisms, a diversity gradient is observed in areas near the spot boundary limits of most central areas. The variation explained by axis 1 was 0.47 and by Axis 2, 0.24 . The quantitative index used was Bray-Curtis.
Fig 2 Temporal variation of percentage of positive sites of Aedes aegypti and Aedes albopictus ( $n=80$ bromeliads sites).

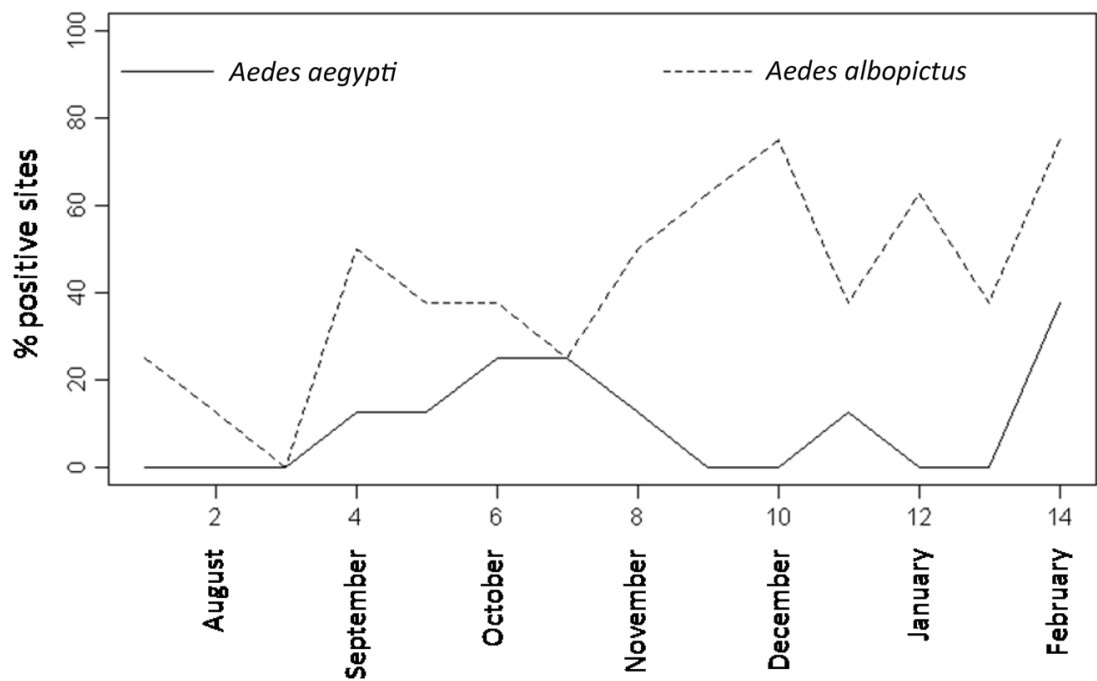

Months 


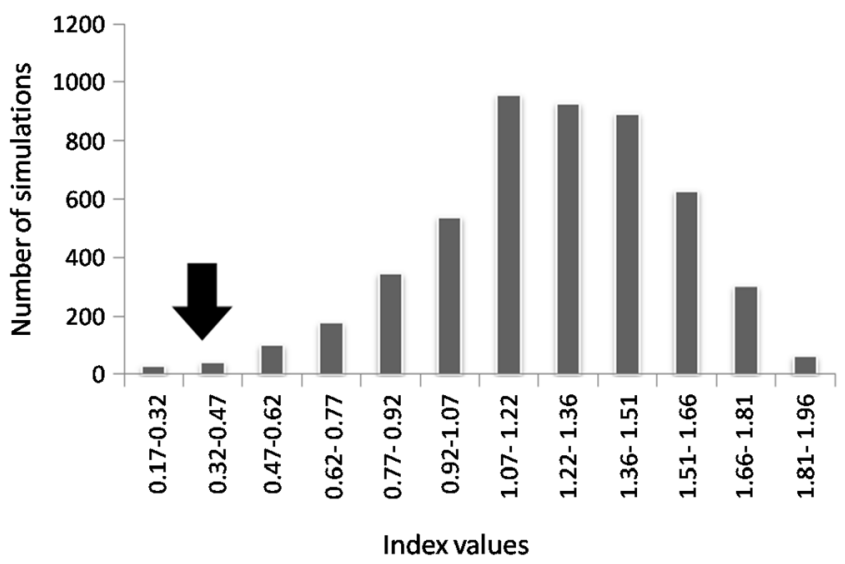

Fig 3 Null model for co-occurrence of immatures [observed index $=0.46$, average of simulated indices $=1.25$, variance of simulated indices $=0.09, p$ (observed $\leq$ expected) $=0.01, p$ (observed $\geq$ expected $)=0.98]$.The arrow indicates the value of the co-occurrence index from actual data.

\section{Discussion}

\section{Abiotic variables}

In this study, we observed a variation of physicochemical properties in the water of bromeliads during the study and among sites with interaction between time and space. In terms of vectors, Ae. albopictus individuals were related positively to intermediate temperature variable values (between 26 and $28^{\circ} \mathrm{C}$ ). Aedes aegypti did not reveal significant patterns. In their study on the development of immature Ae. albopictus, Calado \& Navarro-Silva (2002) revealed the most appropriate track to maintain this stage under laboratory

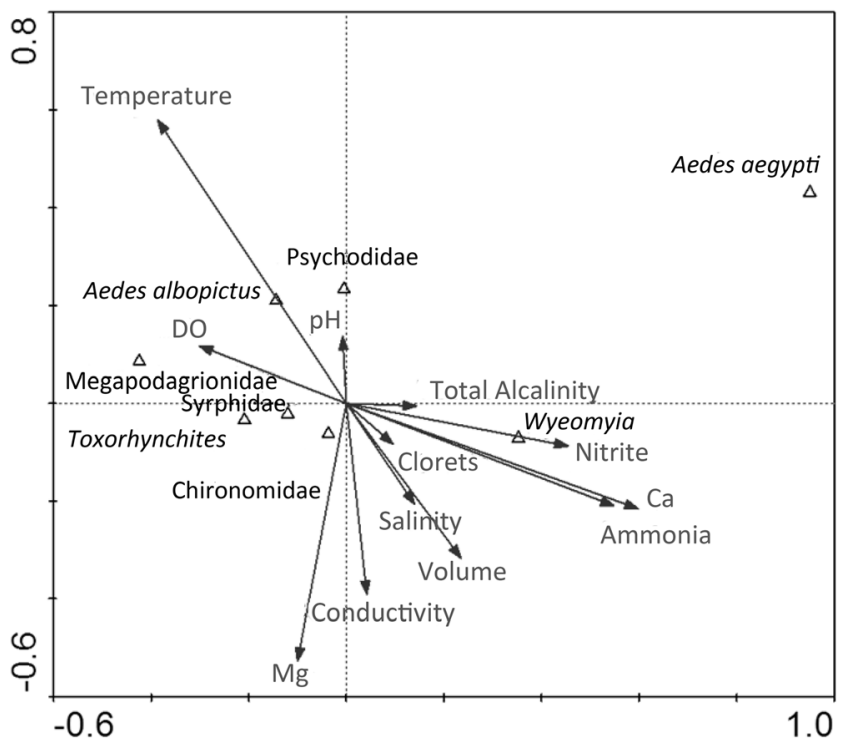

Fig 4 Ordination diagrams extracted by canonical correspondence analysis of the 8 groups entomofauna distribution in relation to habitat variables found significant $(p<0.05)$ (axis 1: eigenvalues $=0.31$; axis 2 : eigenvalues $=0.28$ ). conditions as between $20^{\circ} \mathrm{C}$ and $30^{\circ} \mathrm{C}$, consistent with the current study. Abiotic factors may influence the presence of mosquitoes in bromeliads, but, owing to the low number of individuals of Ae. Aegypti, it was impossible to investigate this association.

\section{Biotic variables}

Among 1309 mosquito larvae collected in bromeliads $80 \%$ of them belong to Wyeomyia genus, characterizing these plants as their preferred habitat. Two endemic mosquito species of southern Florida, Wyeomyia vanduzzei Dayer \& Knab and Wyeomyia mitchellii (Theobald), are also prevalent in bromeliads (Frank 1983). The leaves of trees falling in bromeliads provide a nutritional organic base for larval growth of these species (Frank \& O'Meara 1985). Another possible reason for the accumulation of Wyeomyia larvae collected in phytotelmatas may be attributed to the delay in their development due to nutritional factors. The larvae can remain in this stage for weeks or months until they locate new food resources in their microhabitat (Frank \& Curtis 1977, Frank 1983).

This slow development of larvae of the Wyeomyia genus can be related to the number of adults collected being lower than Ae. albopictus, which possibly emerges more quickly than the former, making it difficult to collect (Forattini 2002). However, Lounibos et al (2003) observed between bromeliad mosquitoes in Florida that the survival of $A e$. albopictus had a significant inverse correlation with the presence of Wyeomyia larvae. This species are also observed in artificial containers and the holes of trees (Lounibos et al 2001 Juliano et al 2002).

Although the presence of Ae. aegypti in bromeliads in urban centers was reported, only a low amount of specimens was found in the examined bromeliads (Varejão et al 2005). The present study indicated that the largest presence of $A e$. aegypti ocurred in the area located on the edge of the campus, close to the local community (Manguinhos region), corroborating observation of Tauil (2001) who commented that the uncontrolled spread of neighborhoods has contributed to vector proliferation. Nine to $14 \mathrm{Ae}$. aegypti individuals were observed in the samples during the summer months (December to February); these numbers decreased in winter (Fig 2), owing possibly to increased rainfall during that period, and, consequently, to an increase in artificial breeding. Another hypothesis is selection pressure (Christophers 1960), which posits that $A$ e. aegypti is more vulnerable to predation and cannibalism.

On the other hand, Ae. albopictus was found in abundance, predominantly at sites $E, F$, and $G$. The sites varied widely in the presence of Ae. aegypti and Ae. albopictus throughout the months, and among one another. The latter was represented by a larger number of positive plots relative to Ae. aegypti. The presence of Ae. aegypti was rare, and the few specimens found 


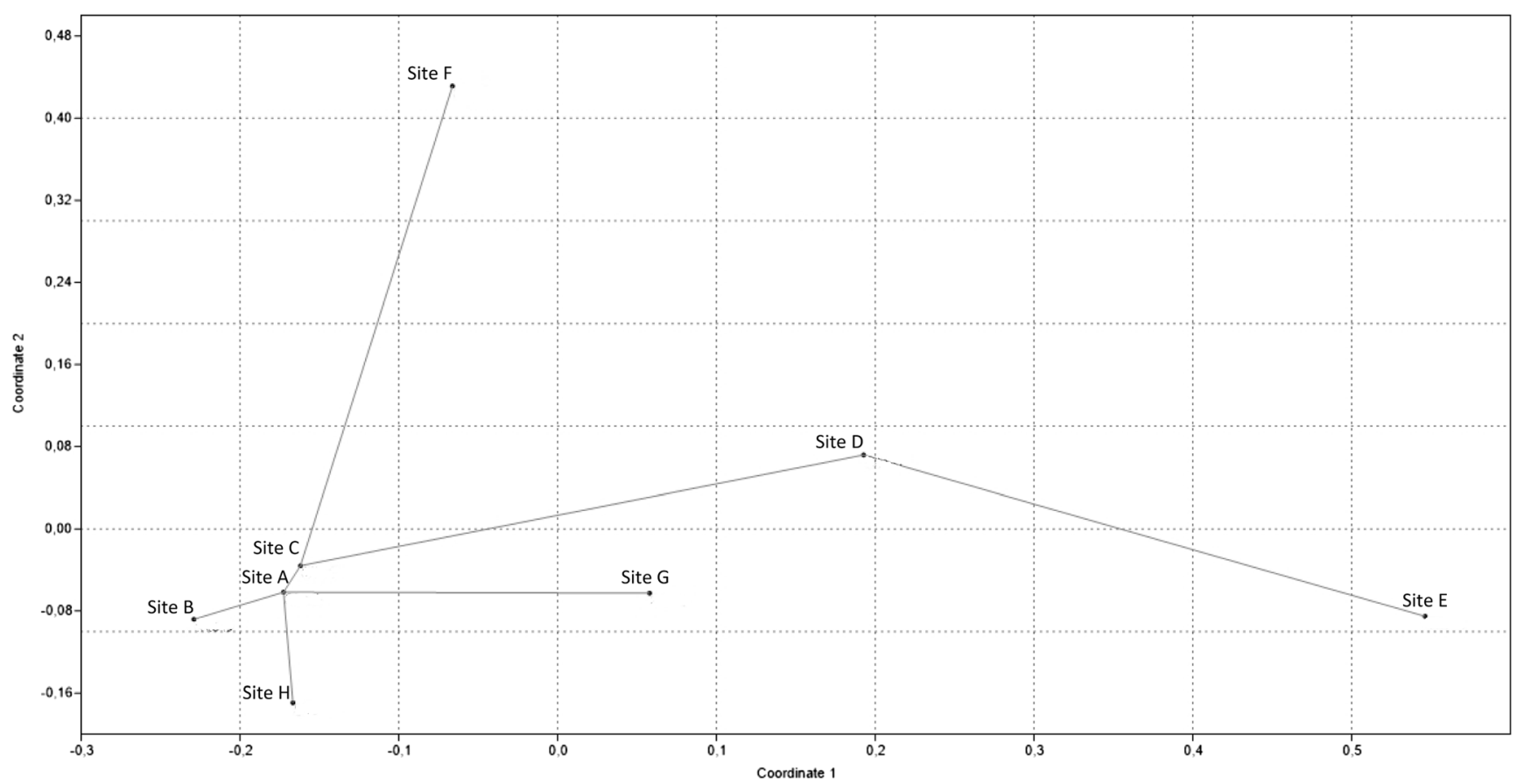

Fig 5 PCO performed using the abundances, where the first coordinate shows a set of sites with very similar entomofauna composition (sites A, B, C, $\mathrm{H})$ and sites with distinct community structure $(F, D, G, E)$.

in the summer were at sites $A, B$, and $F$, which are close to the campus boundary and in a predominantly-urbanized area.

The location of the phytotelmatas of these sites also enabled the distribution of these groups, as the proximity to the local community facilitates the presence of Ae. aegypti and Ae. albopictus. In more central areas of the campus with greater vegetation cover, Ae. aegypti and Ae. albopictus were not found; only characteristic forest area groups, such as wild mosquitoes of the Wyeomyia genus, were identified. This result reinforces the hypothesis that these Aedes species prefer laying eggs in artificial containers and that this contributes to the higher acidity of the bromeliad water (Lopez et al 2011).

Our results indicate that Ae. albopictus was more abundant in areas with high vegetation cover. These results are consistent with Ae. aegypti distribution patterns (in urban areas) and with Ae. albopictus (in more populated areas covered with vegetation) found in the literature (Lourenço-deOliveira et al 2004, Rey et al 2006, Lima-Camara et al 2006, Honorio et al 2009).

Urban environments seem to favor the presence of $A e$. aegypti, since this species lays eggs and is frequently found inside the homes, known as endophytic habit. Furthermore, they feed on human blood, known as anthropophilic habit (Barata et al 2001, Thavara et al 2001). Rural areas seem to favor Ae. albopictus, in its exophilic character, as this species often lays eggs, rests, and performs bloodfeedings in environments in which the vegetation cover is greater (Hawley 1988).

These habits displayed by Ae. aegypti suggest that populations of this species maintain high contact with humans, which is an important parameter in determining the vectorial capacity for the transmission of dengue virus. A study conducted in Rio de Janeiro/Brazil, indicated that denselypopulated neighborhoods located close to highways with intense traffic can facilitate the introduction and circulation of dengue viruses (Lourenço-de-Oliveira et al 2002, Lagrotta et al 2008).

In general, the richness of mosquito species present in bromeliads cups was less than that reported in the literature (O'Meara et al 2003, Marques \& Forattini 2008, Mocellin et al 2009). Mocellin et al (2009) conducted a study near a rainforest region where they found 14 species of mosquitoes in bromeliads, and in the present study, only four species were found. This fact can be observed, whereas in stable ecosystems, such as rainforests, have high species diversity (Richardson 1999), in contrast to studies in small forest area in an urban area.

\section{Association with abiotic variables}

CCA analysis indicated a positive association between greater amounts of immature forms of insect fauna and higher water temperatures. This is probably caused by the activity of mating and egg-laying at higher temperatures (Forattini 2002). Abiotic factors, such as temperature and $\mathrm{pH}$, affect the concentration of organic matter in the water (Esteves 1998). Urban substrates are rich in organic matter, which causes high chemical and biochemical oxygen consumption, decreased $\mathrm{pH}$, and, consequently, increased nutrient reactions, showing toxicity affecting the aquatic biota (Allan 1995, 
Brigante \& Espínola, 2003, Ometto et al 2004, Salomoni et al 2007). Therefore, the composition of the biota is taken as a parameter that reflects the environmental conditions and integrates the influences of water quality and habitat degradation (Lammert \& Allan 1999).

\section{Conclusion}

Bromeliads in locations near human dwellings have higher rates of Aedes compared to areas with greater vegetation cover. During the summer months, Ae. albopictus proliferate in bromeliads. Abiotic variables, such as temperature and dissolved oxygen, positively influence the distribution of the genus Aedes vectors, while most other variables negatively influence this distribution. Owing to the low number of individuals, bromeliad is not a preferred breeding site for $A e$. aegypti, not requiring the reduction of bromeliad populations as a preventive measure to mosquito control in the area of the present study. It is important to emphasize the need to improve vector control in infested municipalities with Ae. aegypti, since only this species in Brazil is, to date, associated with severe transmission of three arboviruses, dengue, Chikungunya, and Zika. Epidemiological surveillance faces an enormous challenge in the early detection of new areas of transmission to minimize the impact of these diseases in the population.

Acknowledgments To Célio Pinel, Carmen Pinheiro and Luciene for their help in field work and all core team of the Núcleo Operacional Sentinela de Mosquitos Vetores-NosMove (Parceria DIRAC-IOCVPAAPS). To LabGeo, especially to Msc. Renata Grazie and Msc. Mônica Magalhães for their help with the construction of the map. This study was partially funded by Conselho Nacional de Desenvolvimento Científico e Tecnológico (CNPq).

\section{References}

Aitken TH, Anderson CR (1959) Virus transmission studies with Trinidadian mosquitoes II. Further observations. AmJTrop Med Hyg 8:41-45

Allan JD (1995) Stream ecology: structure and function of running waters. Chapman and Hall, London, p 388

Barata EAMF, Costa AIP, Neto FC, Glasser CM, Barata JMS, Natal D (2001) População de Aedes aegypti (I.) em área endêmica de dengue, Sudeste do Brasil. Rev Saude Publica 35:237-242

Benzing DH, Titus JE, Derr JA (1972) Water chemistry of microcosms associated with bromeliad Aechmea bracteata. Am Midl Nat 87:6070

Bower CE, Holm-Hansen T (1980) A salicylate-hypochlorite method for determining ammonia in seawater. Can J Fish Aquat Sci 37:794-798

Brigante J, Espínola ELG (2003) Limnologia fluvial: um estudo no Rio Mogi-Guaçu. RiMA, São Carlos
Calado DC, Navarro-Silva MA (2002) Evaluation of the temperature influence on the development of Aedes albopictus. Rev Saude Publica 36(2):173-179

Chaves LF, Koenraadt CJM (2010) Climate change and highland malaria: fresh air for a hot debate. Q Rev Biol 85:27-55

Christophers SR (1960) Aedes aegypti (L.) the yellow fever mosquito. Cambridge University Press, London, p 739

Consoli RAGB, Lourenço-de-Oliveira R (1994) Principais mosquitos de importância sanitária no Brasil. Fiocruz, Rio de Janeiro, p 225

$R$ Core Team (2014) R: A language and environment for statistical computing. R Foundation for Statistical Computing, Vienna, Austria. URL http://www.R-project.org/

Costa RR, Fernandes TM (2009) História de Pessoas e Lugares: memórias das comunidades de Manguinhos. Editora FIOCRUZ, Rio de Janeiro

Cunha SP, Carreira Alves JR, Lima MM, Duarte JR, Barros LCV, Silva JL, Gammaro AT, Monteiro Filho OS, Wanzeler AR (2002) Presença de Aedes aegypti em Bromeliaceae e depósitos com plantas no município do Rio de Janeiro, RJ. Rev Saude Publica 36:244-245

David MR, Lourenço-de-Oliveira R, Maciel-de-Freitas R (2009) Container productivity, daily survival rates and dispersal of Aedes aegypti mosquitoes in a high income dengue epidemic neighborhood of Rio de Janeiro: presumed influence of differential urban structure on mosquito biology. Mem Inst Oswaldo Cruz 104:927-932

Esteves FA (1998) Fundamentos de Limnologia. Editora Interciência/ FINEP, Rio de Janeiro, p 601

Figueiredo LT (2007) Emergent arboviruses in Brazil. Rev Soc Bras Med Trop 40:224-229

Figueiredo ML, Figueiredo LT (2014) Emerging alphaviruses in the Americas: Chikungunya and Mayaro. Rev Soc Bras Med Trop 47: 677-683

Forattini OP (1965a) Entomologia Médica. Culicini: Haemagogus, Mansonia, Culiseta, Sabethini, Toxorhynchitini. Arboviroses, Filariose bancrofitiana. Genética, vol 1. Editora Universidade de São Paulo, São Paulo, p 416

Forattini OP (1965b) Entomologia Médica. Culicini: Culex, Aedes, e Psorophora, vol 2. Editora Universidade de São Paulo, São Paulo, p 506

Forattini OP (2002) Culicidologia Médica. Identificação, Biologia, Epidemiologia, vol 2. Editora Universidade de São Paulo, São Paulo, p 860

Forattini OP, Marques GRAM (2000) Nota sobre o encontro de Aedes aegypti em bromélias. Rev Saude Publica 37(6):729-734

Forattini OP, Marques GRAM, Kakitani I, Brito M, Sallum MAM (1998) Significado epidemiológico dos criadouros de Aedes albopictus em bromélias. Rev Saude Publica 32:186-188

Frank JH (1983) Bromeliad phytotelmata and their biota, especially mosquitoes. In: Frank JH, Lounibos LP (eds) Phytotelmata: terrestrial plants as hosts for aquatic insect communities. U.S.A. Plexus Publishing, Medford, pp 101-128

Frank JH, Curtis GA (1977) On the bionomics of bromeliad inhabiting mosquitoes. III. The probable strategy of larval feeding in Wyeomyia vanduzeei and Wyeomyia medioalbipes. Mosq News 37:200-206

Frank JH, O'Meara GF (1985) Influence of micro- and macrohabitat on distribution of some bromeliad-inhabiting mosquitoes. Entomol Exp Appl 37:169-174

Funasa (2006) Fundação Nacional de Saúde. Manual de Saneamento, 4th edn. Fundação Nacional de Saúde, Brasília

Gadelha P (1994) From "forest malaria" to "bromeliad malaria": a casestudy of scientific controversy and malaria control. Parasitol 36:175195

Gotelli NJ, Entsminger GL (2009) EcoSim: null models software for ecology, v.7. Acquired Intelligence Inc and Kesey-Bear [software on the Internet]. Published by the authors. Available from: garyentsminger. com/ecosim. Accessed 18 Apr 2011 
Hammer O, Harper DAT, Ryan PD (2001) PAST - Palaeontological Statistics

Hawley WA (1988) The biology of Aedes albopictus. J Am Mosq Control Assoc Suppl 1:1-39

Honorio NA, Castro MG, Barros F, Magalhães M, Sabroza P (2009) The spatial distribution of Aedes aegypti and Aedes albopictus in a transition zone, Rio de Janeiro, Brazil. Cad Saude Publica 25(6):1203-1214

Inselsbacher EC, Cambui A, Richter A, Stange CF, Mercier H, Wanek W (2007) Microbial activities and foliar uptake of nitrogen in the epiphytic bromeliad. Vriesea Gigantea. New Phytol 175:311-320

loos S, Mallet HP, Goffart IL, Gauthier V, Cardoso T, Herida M (2014) Current Zika virus epidemiology and recent epidemics. Med Mal Infect 44:302-307

Juliano SA, O'Meara GF, Morrill JR, Cutwa MM (2002) Desiccation and thermal tolerance of eggs and the coexistence of competing mosquitoes. Oecol 130:458-469

Lagrotta MF, Silva WC, Souza-Santos R (2008) Identification of key areas for Aedes aegypti control through geoprocessing in Nova Iguaçu, Rio de Janeiro state, Brazil. Cad Saude Publica 24:70-80

Lammert M, Allan JD (1999) Assessing biotic integrity of streams: effects of scale in measuring the influence of land use/cover on habitat structure on fish and macroinvertebrates. Environ Manag 23(2): 257-270

Lane J (1953a) Neotropical Culicidae. Vol. 1. São Paulo, Press in University of São Paulo, p 548

Lane J (1953b) Neotropical Culicidae. Vol. 2. São Paulo, Press in University of São Paulo, $\mathrm{p} 1112$

Lenzi MF, Camillo-Coura L, Grault CE, Val MB (2000) Estudo do dengue em área urbana favelizada do Rio de Janeiro: considerações iniciais. Cad Saude Publica 16:851-856

Lima-Camara T, Honório NA, Lourenço-de-Oliveira R (2006) Freqüência e distribuição espacial de Aedes aegypti e Aedes albopictus (Diptera, Culicidae) em distintos ambientes no Rio de Janeiro, Brasil. Cad Saude Publica 22:2079-2084

Lopez LCS, Alves RRD, Rios RI (2009) Microenvironmental factors and the endemism of bromeliad aquatic fauna. Hydrobiol 625:151-156

Lopez LCS, Silva EGB, Beltrão MG, Leandro RG, Barbosa JEL, Beserra EB (2011) Effect of tank bromeliad micro-environment on Aedes aegypti larval mortality. Hydrobiol 665:257-261

Lounibos LP, O'Meara GF, Escher RL, Nishimura N, Cutwa M, Nelson T, Campos RE, Juliano SA (2001) Testing predictions of displacement of native Aedes by the invasive Asian Tiger mosquito, Aedes albopictus in Florida, U.S.a. Biol Invasions 3:151-166

Lounibos LP, O'Meara GF, Escher RL, Nishimura N (2003) Interactions with native mosquito larvae regulate the production of Aedes albopictus from bromeliads in Florida. Ecological Entomol 28:551-558

Lourenço-de-Oliveira R, Honório NA, Castro MG, Schatzmayr HG, Miagostovich MP, Alves JCR (2002) Dengue virus type 3 isolation from Aedes aegypti in the municipality of Nova Iguaçu, state of Rio de Janeiro. Mem Inst Oswaldo Cruz 97:799-800

Lourenço-de-Oliveira R, Castro MG, Braks MAH, Lounibos LP (2004) The invasion of urban Forest by dengue vectors in Rio de Janeiro. J Vector Ecol 29:94-100

Maciel-de-Freitas R, Marques WA, Peres RC, Cunha SP, Lourenço- deOliveira R (2007) Variation in Aedes aegypti (Diptera: Culicidae) bromeliad mosquitoes in dengue a container productivity in a slum and a suburban district of Rio de Janeiro during dry and wet seasons. Mem Inst Oswaldo Cruz 102:489-496
Marques GRAM, Forattini OP (2008) Culicídeos em bromélias: diversidade de fauna segundo influência antrópica, litoral de São Paulo. São Paulo Rev Saude Publica 42(6):979-985

Marques GRAM, Santos RLC, Forattini OP (2001) Aedes albopictus em bromélias de ambiente antrópico no estado de São Paulo, Brasil. Rev Saude Publica 35:243-248

Mocellin MG, Simoes TC, Nascimento TFS, Teixeira MLF, Lounibos LP, Oliveira RL (2009) Bromeliad-inhabiting mosquitoes in an urban botanical garden of dengue endemic Rio de Janeiro. Are bromeliads productive habitats for the invasive vectors Aedes aegypti and Aedes albopictus. Mem Inst Oswaldo Cruz 104:1171-1176

Motta MA, Lourenço-de-Oliveira R, Sallum MAM (2007) Phylogeny of genus Wyeomyia (Diptera; Culicidae) inferred from morphological and allozyme data. Can Entomol 139:591-627

Natal D, Urbinatti PR, Taipe-Lagos CB, Cereti-Junior W, Diederich ATB, Souza RG (1997) Encontro de Aedes (Stegomyia) albopictus (Skuse) em Bromeliaceae na periferia de São Paulo, SP, Brasil. Rev Saude Publica 31:517-518

O'Meara GF, Cutwa MM, Evans LF (2003) Bromeliad inhabiting mosquitoes in South Florida: native and exotic plants differ in species composition. J Vector Ecol 28:37-46

Ometto JP, Gessner A, Martinelli LA, Bernardes MC (2004) Macroinvertebrate community as indicator of landuse changes in tropical watersheds, southern Brazil. Ecohydrol Hydrobiol 4:37-49

Ortiz DI, Kang W, Weaver SC (2008) Susceptibility of Ae. aegypti (Diptera: Culicidae) to infection with epidemic (subtype IC) and enzootic (subtypes ID, IIIC, IIID) Venezuelan equine encephalitis complex alphaviruses. J Med Entomol 45:1117-1125

Peryassú AG (1908) Os culicideos do Brasil. Instituto de Manguinhos, R.J. Brazil, p 407

Rey JR, Nishimura N, Wagner B, Braks MAH, O'Connell SM, Lounibos LP (2006) Habitat segregation of mosquito arbovirus vectors in South Florida. J Med Entomol 43:1134-1141

Richardson BA (1999) The bromeliad microcosm and the assessment of faunal diversity in a neotropical forest. Biotropica 31:321-336

Richardson BA, Rogers C, Richardson MJ (2000) Nutrients, diversity, and community structure of two phytotelm systems in a lower montane forest, Puerto Rico. Ecol Entomol 25:348-356

Salomoni SE, Rocha O, Leite EH (2007) Limnological characterization of Gravataí River, Rio Grande do Sul. Acta Limnol Bras 19:1-14

Stone L, Roberts A (1990) The checkerboard score and species distributions. Oecol 85:74-79

Tauil PL (2001) Urbanização e ecologia do Dengue. Cad Saude Publica 17(Supl I):99-102

Ter Braak CJF, Smilauer P (2002) CANOCO reference manual and CanoDraw for windows user's guide: software for canonical community ordination (version 4.5). Ithaca, Microcomputer Power, $p$ 500

Thavara U, Tawatsin A, Chansang C, Kong-Ngamsuk W, Paosriwong S, Boon-Long J (2001) Larval occurrence, oviposition behavior and biting activity of potential mosquito vectors of dengue on Samui Island, Thailand. J Vector Ecol 26:172-180

Varejão JBM, Santos CB, Rezende RH, Bevilacqua LC, Falqueto A (2005) Criadouros de Aedes (Stegomyia) aegypti (Linnaeus, 1762) em bromélias nativas na cidade de Vitória, ES. Rev Soc Bras Med Trop 38:238-240 